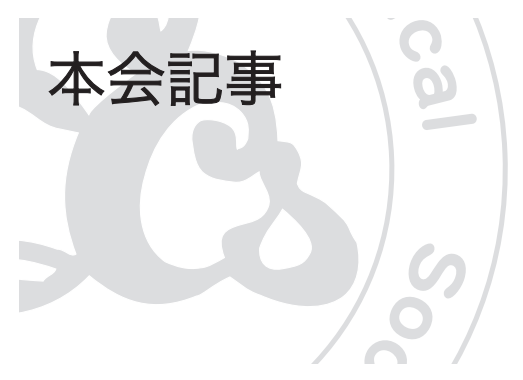

\title{
PRiME2016 報告
}
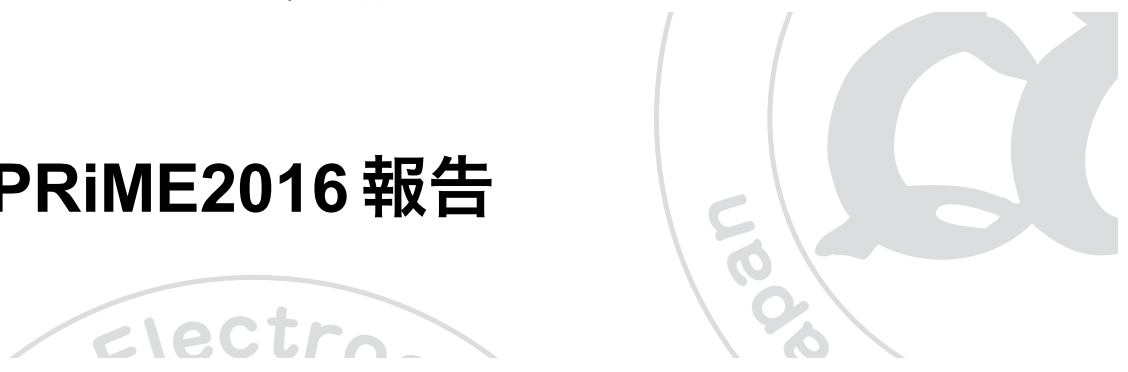

2016 年 10 月 2 日〜 7 日の 6 日間，ハワイ州ホノルル市 ハワイコンベンションセンター $(\mathrm{HCC})$ で, PRiME2016が 開催された。ハワイで開催される電気化学大会として通 算 7 回目, PRiMEと改称されてから 3 回目となる。 PRiME2012 までは米国電気化学会 (ECS) と本会の主催で あり, 応用物理学会, 韓国電気化学会 (KECS), オースト ラリア王立化学会の電気化学部門, 中国電気化学会が共 催団体であった。 今大会から，KECSが主催に加わり，共 催には韓国物理学会・半導体部門と中国物理学会・半導 体部門が加わった。

日本語訳で「環太平洋電気化学大会」と言う会議名称 は主催・共催団体から見て, より相応しくなった。今回は 世界 67 力国から 3,961 名の参加者があった．前回の 2012 年大会（3,811 名）を上回り，まさに電気化学における世 界最大，史上最大の学会となった。 日本からの参加者は前 回に引き続き国別では最大で 1,391名であった。前回は 1,322 名であったので記録を毎回更新していることになる。

前回大会では講演数（口頭発表とポスター発表の総数） が4,000 件を越え, 全てのシンポジウムを当初予定してい た HCCのみに収容できず，やむを得ずヒルトンハワイア ンビレッジ $(\mathrm{HHV})$ を併用したので会場間の移動がやや不 便であった。今大会の講演数は 4,169 件で, これも記録を 更新したが，実行委員会の強いリーダーシップのもとで， シンポジウムの統合と講演会場の効率的運用により HCC のみでの開催が実現できた。

$\mathrm{HCC}$ での参加受付は 10 月 1 日（土）の 16 時から開始 された Fig. 1), 日曜日午前中からのシンポジウムに備え て先着した会員も多く見られた。数年前のECSの通常大 会から，参加者自身がパソコンから氏名を入力し，プリ ンターから名札やイベントの参加証が印刷される形式と なった。 今回は, KECS と本会の学生会員が参加受付のト ラブル対応を担っていたが，幸い大きな混乱も無かった ようである。

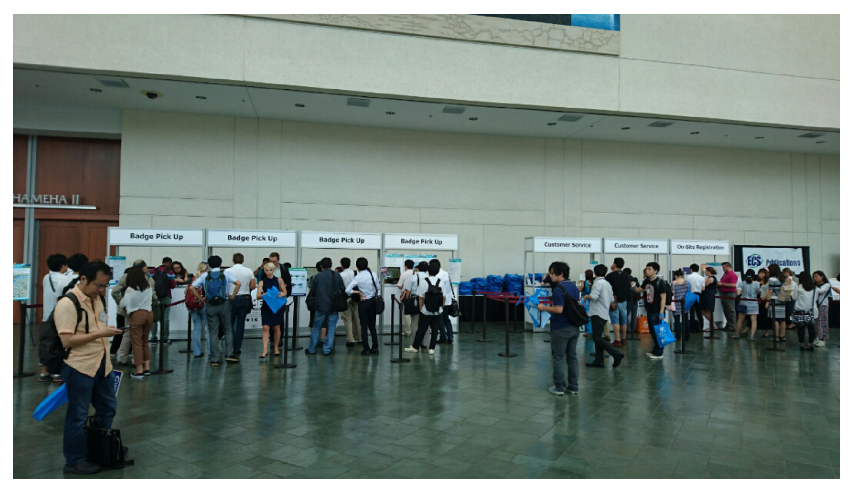

Figure 1. (Color online) HCC での参加受付.
会期中は時々小雨もあったが，天候にもまずまず恵ま れ，八ワイの美しい自然を満喫するとともに日頃の成果 を発表・議論し，また旧交を温めることができた。

電池, 燃料電池, 半導体デバイス等のシンポジウムは 初日 10 月 2 日（日）の早朝から開始された。初日の 16 時 からは，第 6 回国際電気化学エネルギーサミットが開催 された。八ワイ州エネルギー局，米国から DOE，韓国か ら KIER, 日本から NEDO の代表者が基調講演を行い, 会 場はほぼ満員であった。 ハワイの環境保全に対する電気 化学の重要性が再認識された. 月曜日の夕方には, 会の フォーマルな全体会議が行われた。本会の西原 寛会長, KECS の Yongkeun Son 会長と ECS の Krishnan Rajeshwar 会長が開会の挨拶をされた (Fig. 2). ECS 各賞の表彰の後, Michael Grätzel 教授（スイス連邦工科大学ローザンヌ校） による “Photoelectrochemical Cells for the Generation of Electricity and Fuels from Sunlight” と題する基調講演は, 立ち 見が出るほどの盛況であった.

学生の参加者数が多いのも PRiMEの特徵であろう. ECS の統計によると, 学生による発表数は 1,372 件で 約 33\%に達している. 内訳は口頭発表 657 件, ポスター 715 件であった。炎曜日の夕方には General Student Poster Session が行われ (Fig. 3)，214 件（前回は231 件）のポス ターが発表された。2012 年大会から, 本会からの審査員 と ECS からの審査員の数を同数とし, 発表内容のレベル に見合ったポスター賞の選考になるように改善された。 1 次審査はポスターの内容とその出来映えで選ばれる. 2 次審査は審査員グループがインタビューして順位を決め ることになる。このような審査の結果, Electrochemical Science and Technology 部門で 2 名（2 位：松村祥太氏（大 阪府大)，3 位：坂田日和氏 (信州大)), Solid-State Science and Technology 部門で 2 名（加藤真洋氏（日本大

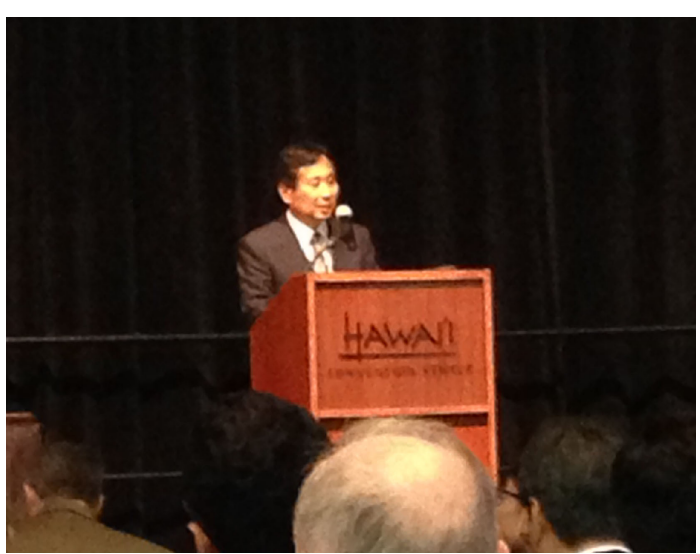

Figure 2. (Color online) 開会の挨拶をする西原 寛電気化学 会会長。 


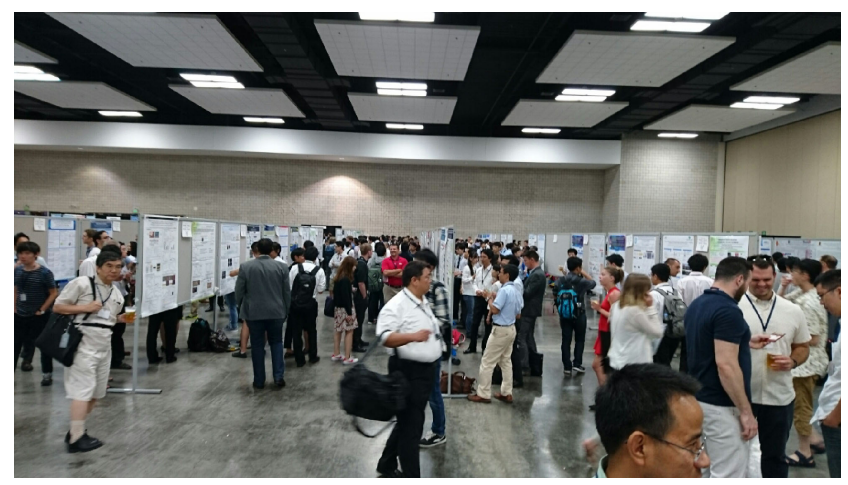

Figure 3. (Color online) General Student Poster Session.

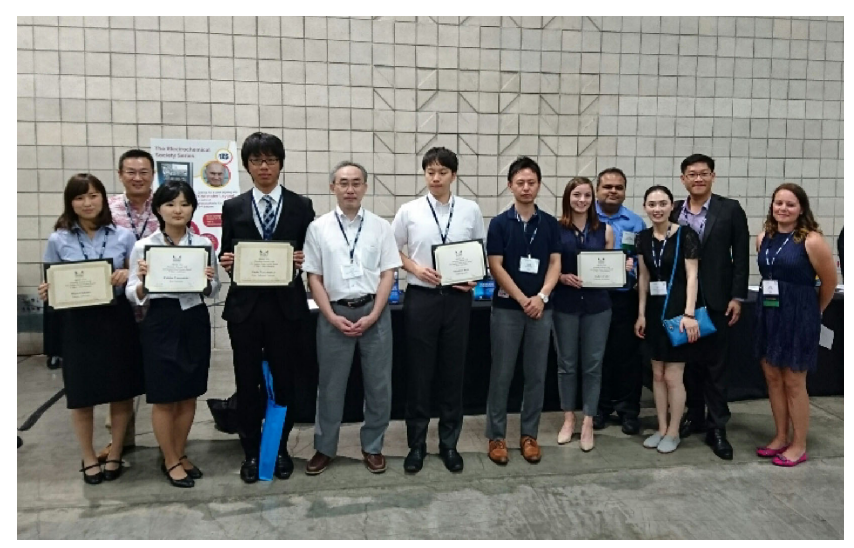

Figure 4. (Color online) Student Poster Award を受賞した本会 学生会員（左端より賞状を持っている坂田, 山元, 松村, 加 藤の各氏）と関係者。

1 位), 山元二葉氏 (慶応大 2 位 $)) \varepsilon$, 計 5 名の受賞者の うち 4 名が本会の学生達が選ばれ，その実力が認められ る結果となった (Fig. 4). 受賞した学生達には心から祝意 を表したい。言うまでも無く, 国際学会でのポスター賞 等の受賞は大きな励みになる。先生方には，引き続き， ポスターの完成度とともに審査を想定した要領を得た説 明と質疑応答を学生に指導頂ければと思う。

6 日間の会議では，57 のシンポジウムが口頭発表およ びポスター発表で行われた。多くは順調に進んだと推察 されるが，前述のように 1 会場での開催のため，午前 7 時 40 分から講演を開始したり, 最終日 18 時まで講演が隙間 無く詰まっていたシンポジウムもあった。 また, 講演会 場の効率的運用のために, 昼休みの短縮もお願いしたの でゆとりが無かったかもしれない. 今回の経験をもと に, シンポジウムの統合がもう少し進めば改善されるが, なかなか困難な点もあるので, 今後の検討課題としたい. 他方, 講演 Abstract の Web 公開日が明確でなかったので, 特許申請に差し支えるとの苦情も頂いた。この点は次回 から改善される見通しである。

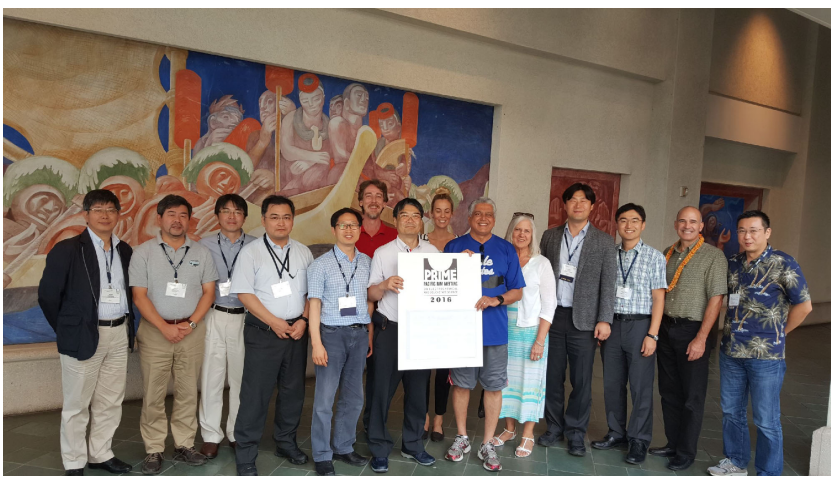

Figure 5. (Color online) 最終日の実行委員会後の集合写真.

なお，会期中に，ECS，KECS と本会の幹部や事務職員 が夕食会で親睦を深める努力を行っていることも申し添 えておきたい. 本大会のバンケットであるLuauは，6日 (木) の夕刻, HHV 内のラグーンに隣接する野外会場で 行われた. 主催 3 学会の会長がラグーンからカヌーに 乗って登場し参加者を沸かせた. 様々なポリネシアン ショーは何時もながら喝采を浴びていた. 最終日には実 行委員会が開催され, 今大会の総括と次回への課題が議 論された(Fig. 5).

1987 年の第 1 回日米合同大会以来, PRiME2012 まで 25 年続いてきた本会と ECS との合同大会, KECS が新たに 主催に加わった今大会が円滑に運営される基軸となって いるのは, やはり本会とECS との摇るぎない信頼関係で あり, これは歴代の組織委員長, 幹事長等, 関係各位の ご尽力の賜である。関係各位に心から感謝申し上げたい. 今大会に関しては, 片山 靖・副委員長（前回大会の幹 事長), 杉本 渉 - 幹事長, Solid-State Science and Technology 分野から新宮原正三・委員が実行委員会で細かい 調整を図って頂いた。 また, 高見澤 正・事務局長, 石 渡佐敏・前事務局長を始めとする学会職員の方々からも 準備期間中の会員への種々の連絡や宣伝活動など，さま ざまな支援を頂いた。厚く御礼申し上げる。

Call for Papers の段階から, 各シンポジウムの運営に ECS ディビジョンに加えて本会の専門委員会・研究懇談 会が加わることはすっかり定着し, このような協働は通 常の ECS 大会にも継続されている. PRiME各シンポジウ 厶運営への KECS や CSEの寄与も増え, 通常の ECS 大会 にも継続して組織委員が残つて協力する体制も出来つつ ある. 次回の PRiMEは, 2020 年に片山 靖組織委員長の もと行われる予定である. 今回の反省点は実行委員会で 共有しているので, これらを検討し, さらなる発展と成 功を祈念している.

(PRiME2016 日本側組織委員長・山梨大学 内田 裕之) 